\title{
Relationship Between Adolescents' Health Promoting Lifestyle Behaviors and Self-Efficacy
}

\section{Ergenlerin Sağlıkı Yașam Biçimi Davranıșları ve Öz-Yeterlilikleri Arasındaki llișki}

\author{
Şeyda Binay1, Rana Yiğit2 \\ ${ }^{1}$ Ege University Faculty of Nursing, Department of Pediatric Nursing, Izmir, Turkey \\ 2 Mersin University Faculty of Health, Department of Pediatric Nursing, Mersin, Turkey
}

\section{ABSTRACT}

Aim: This research aims to determine the relationship between healthy lifestyle behaviors and self sufficiency of adolescents.

Materials and Methods: The sample of this descriptive study has been constituted by 1749 students who were chosen via the stratified random sampling method. The students were picked from among the first graders of 12 different high schools, taking into consideration the type of school. In collecting the data for the study, Personal Information Form, giving identifying information about the 13-16 year-old adolescents; the Health Promoting Lifestyle Profile (HPLP) developed by Walker, Sechrist and Pender (1987); and the General Self-Efficacy Scale (GSE) by Jerusalem and Schawazzer (1979) were applied. The analysis of the data obtained from this study was done by Shapiro Wilk test, Student t test, ANOVA test and Tukey honest significant difference test.

Results: The HPLP average score of adolescents was $127.88 \pm 21.16$ and at middle level; GSE average score was $31.53 \pm 5.02$ and above middle level. The GSE and HPLP average scores of the male students were higher than those of the female students. It was found that the mean scores of HPLP were moderately correlated with GSE scale mean scores $(r=0.471)(p<0.001)$. Conclusion: As a result, adolescents must have appropriate skills in order to perform healty lifestyle behaviours. Self-Efficacy is an important factor in the acquisition of these skills.

Keywords: Adolescent, healthy promoting lifestyle, self-efficacy, nursing
ÖZ

Amaç: Araşıırmanın amacı ergenlerin sağlıkı yaşam biçimi davranışları ile öz-yeterlilikleri arasındaki ilişkinin incelenmesidir.

Gereç ve Yöntemler: Tanımlayıcı olan çalışmanın örneklemini okul tipleri dikkate alınarak, 12 farkı lisenin birinci sınıf okuyan, tabakalı rastgele örnekleme yöntemi ile seçilen 1749 öğrenci oluşturmaktadır. Veri toplamada, 13-16 yaş grubundaki adölesanlar hakkında tanımlayıcı bilgiler içeren Kişisel Bilgi Formu, Walker, Sechrist ve Pender tarafından (1987) geliştirilen "Sağlıklı Yaşam Biçimi Davranışları Ölçeği" (SYBDÖ) ve Jeruselam ve Schawazzer (1979) tarafından geliştirilen Genel Öz-Yeterlilik Skalası (GÖS) kullanılmıştır. Bu çalışmadan elde edilen verilerin analizi Shapiro Wilk testi, Student t testi, ANOVA testi ve Tukey dürüstçe anlamlı fark testi ile yapılmıştır. Bulgular: Adölesanların SYBDÖ puan ortalaması $127,88 \pm 21,16$ ve orta düzeyde, GÖS puan ortalaması $31,53 \pm 5,02$ ve orta düzeyin üstünde, erkek öğrencilerin GÖS ve SYBDÖ puan ortalaması ise kız öğrencilere göre daha yüksektir. SYBDÖ puan ortalamaları ile GÖS puan ortalamalarının orta düzeyde ilişkili olduğu tespit edilmiştir $(r=0,471)(p<0,001)$.

Sonuç: Adölesan sağlıklı yaşam davranışı gerçekleştirmek için uygun becerilere sahip olmalıdır. Öz yeterlik bu becerilerin kazanılmasında önemli bir faktördür.

Anahtar Kelimeler: Ergen, sağ|ıkı yaşam biçimi, öz-yeterlilik, hemşirelik

\section{Address for Correspondence/Yazısma Adresi}

Şeyda Binay Nurse, Ege University Faculty of Nursing, Department of Pediatric Nursing, Izmir, Turkey

Phone: +90 23238811 03-5572 E-mail: seydabinay@hotmail.com

Received/Geliş tarihi: 15.07.2016 Accepted/Kabul tarihi: 13.10.2016

${ }^{\circ}$ Copyright 2016 by Galenos Yayınevi

The Journal of Pediatric Research published by Galenos Yayinevi. 


\section{Introduction}

Adolescence lasts for approximately ten years (between the ages 12-22), and is characterized with a constant change and development. The temporal scope of adolescence may vary according to culture and gender $(1,2)$. Besides tremendously rapid biological and psychological changes, adolescents may experience stress and pressure due to seemingly unbearable new responsibilities in family, school, work, and social life that will certainly mislead them to risky behaviors $(2,3)$. These changes are particularly important in terms of attitudes and behaviors towards one's health since they particularly influence not only adolescents but also their families and social structure (3). Health Promoting Lifestyle Profile (HPLP) ameliorates individual well-being and ensures self-actualization. Pender et al. (4) argued that a healthy lifestyle is an indispensible component of promoting health. Promoting health especially signifies an objective to enable people to enrich, manage, and enjoy their health in full potential. Another significant factor in promoting health is self sufficiency (5), which is commonly identified with one's determination and belief in their own capacity to fulfill a certain task. An individual's ability to carry out selfcare requirements is also strongly connected to culturally learned behaviors. Behavior acquisition starts in the family and continues through all steps of life. Therefore, it is of utmost importance to create proper learning conditions for individuals according to their physical growth and personal development. Family environment and schools are the center of learning and developing behaviors; especially parents provide substantial role models for their children to adopt HPLP (6). In the health promotion model developed by Pender et al. (4), it is often emphasized that self-efficacy of an individual is a prominent determinant of initiating and maintaining health promoting behaviors. Health promotion model is based on social learning theory and specifically deals with cognitive procedures that have an effect on health promoting behaviors. It places a great emphasis on enhancing individual well-being. Health promoting behaviors in the model are cognitive perception factors (self-efficacy, etc.), variable factors. Health promotion is elemental to lead a happy, prosperous and quality life. Health promotion is considered as a process that strenghtens health condition, shapes attitudes, supports behavioral changes to attain utmost physical and mental health, and organizes social and physical environment of a person $(4,7)$. This is only possible when people activate a rich potential to improve and manage their health and prosperity. A perfect state of health can be achieved by staying away from smoking, alcohol and drugs, violence, and risky sexual behaviors as well as ensuring a healthy diet, physical activity, weight control, positive family relationships, and stress management (8-10). When people establish such habits as their lifestyle, they can be regarded as self-sufficient individuals that can maintain and improve their health (11-13). It is important to ascertain a healthy start and steady improvement at early ages (3). Nurses closely work with individuals and their families from the birth onwards and therefore they undertake a great responsibility to raise awareness of people towards their own health condition, highlight the significance of health promoting behaviors, and support regular practice. Nurses can determine and promote responsibilities of a person to follow the program. They also revise activities and requirements within a systematic program, and are primarily in charge of planning, implementing, and maintaining programs that will help children and young people at schools to acquire health improving and promoting behaviors. In order to implement educational programs specially designed for children and adolescents, it would be instrumental to evaluate the current health promoting lifestyle and self-efficacy.

\section{Materials and Methods}

Sample and survey administration: This descriptive study was conducted in 12 public high schools with different curriculum designs (high schools, vocational high schools, science high schools and high schools with Intense Programs known as Anadolu High Schools) in four different towns (Akdeniz, Mezitli, Toroslar, and Yenişehir) in the province of Mersin. The study universe consisted of 17.261 high school freshmen in 59 high schools in 2010-2011 academic year. The study sample was composed of 1749 first graders in 12 schools. The schools were chosen with random sampling and the students were chosen with stratified random sampling to represent $10 \%$ of all students in the study universe. The researchers deliberately planned to choose equal number of students from each school and therefore 150 students from each high school were included in the study.

\section{Data Collection}

The study data were collected with a Personal Information Form that introduced 13-16 year-old participants, HPLP developed by Walker et al. (14) and General Self-Efficacy Scale (GSES) developed by Schwarzer and Jerusalem (15).

\section{Personal Information Form}

The form included information about students' age, gender, number of siblings, residence, family type, educational status of parents, profession of parents, social security, income, number of people in the family.

\section{Health Promoting Lifestyle Profile}

HPLP was developed by Walker et al. (14) in 1987 and its validity and reliability in Turkey was tested by Esin (16). The scale was a 4 point likert scale and it included 48 items (all positive). Each item was scored as 1 (never), 2 (sometimes), 3 (often) and 4 (regularly). The lowest score was 48 and the highest was 192 with permission of the authors. The scale had 6 subdimensions (health responsibility, exercise, diet, interpersonal support, stress management and selfactualization). The questions in the scale were particularly 
designed to measure health promoting behaviors in relation to health promotion. Higher scores in the scale indicate higher levels of health promoting behaviors (15).

\section{General Self-Efficacy Scale}

GSES was developed by Schwarzer and Jerusalem (15) in 1979 and it was modified into Turkish by Usta Yesilbalkan and Karadakovan (17) after testing it for validity and reliability with patients who were receiving peritoneal dialysis with permission of the authors. The scale was tested for validity and reliability once again by Aypay (18) in 2010 with students. The form included 10 statements each of which was scored from 1 to 4 . The lowest score was 10 and the highest was 40. Higher scores in the scale show higher scores of selfefficacy (16-18).

\section{Data Analysis}

The normal distribution tests of scale scores were conducted with Shapiro Wilk test for all subdimensions. Descriptive statistics of continuous data are given as median and standard deviation values while descriptive statistics of categorical variable are given as number and percentages. Student $t$ test was used to compare the total scores of both groups. The scores of more than two groups were analyzed with ANOVA. Paired comparison of groups was carried out by Tukey honest significant difference test. The study data were analyzed on computer with SPSS 11.5 (Statistical Package for The Social Sciences for Windows).

\section{Ethical Considerations}

A permission in writing was sought from Mersin University Scientific Researches Review Board and Mersin Provincial Directory of National Education. Besides, the students were asked to give oral assent and informed consent was obtained.

\section{Results}

The study results indicated that $48.8 \%$ of the participants were female and $51.2 \%$ of them were male. $71.8 \%$ of them were 15 years old and $79.4 \%$ of the participants spent most of their lives in cities. $77.1 \%$ of the students had nuclear families and $48.7 \%$ of the mothers graduated from primary and secondary schools while $43 \%$ of the fathers were primary school graduates. It was further reported that $76.9 \%$ of the mothers were unemployed. $49.3 \%$ of the participants stated that they had adequate income while $15 \%$ of them stated they didn't. $62.3 \%$ of the participant students reported that they weren't involved in any kind of social activities. $68.4 \%$ of them admitted that their body weight was normal (Table I). Thousand seven hundred forty-nine students fully completed HPLP and their mean subscore was $127.88 \pm 21.16$. On the other hand, their GSES mean subscore was found to be $31.53 \pm 5.02$ (Table II). It was found that mean scores of HPLP were moderately correlated with GSES mean scores $(r=0.471)(p<0.001)$. Students with higher mean scores of HPLP were reported to have higher GSES mean scores (Table III).

\section{Comparison of Adolescents' Socio-demographic Characteristics and Scale Scores}

A statistically significant difference was found between the HPLP mean scores of female and male students $(p<0.001)$. The mean scores of male students were significantly much higher than those of female students. It was also noted that there was a statistically significant difference between the GSES mean scores of male and female students $(p=0.002)$. The average scores of male students were found to be higher than those of female students. The mean scores of HPLP were compared in relation to the school types and it was maintained that the students at Anadolu High Schools had significantly higher HPLP scores $(p<0.001)$. However, no significant difference was reported between GSES mean scores according to the school types $(p=0.124)$. On the other hand, the study results indicated that there was a statistically significant correlation between mothers' educational status and HPLP mean scores $(p<0.001)$. Similarly, a statistically significant difference was reported between the mean scores of students whose mothers were primary school graduates and those whose mothers were high school graduates $(p<0.001)$. Additionally, students whose mothers were high school or university graduates had comparatively higher HPLP mean scores than the students whose mothers were illiterate or primary school graduates $(p<0.001)$. However, no statistically significant difference was found between the education status of mothers and GSES mean scores $(p=0.061)$. The study results suggested a statistically significant correlation between the educational status of fathers and HPLP mean scores $(p<0.001)$. The participants whose fathers graduated from high schools or university and above had higher HPLP mean scores than the participants whose fathers were either illiterate or primary school graduates $(p<0.001)$. It was reported that there was a statistically significant difference between the educational status of fathers and GSES mean scores $(p=0.004)$. The students whose fathers were high school graduates had higher GSES mean scores than those whose fathers were illiterate or primary school graduates. The study results also pointed out a statistically significant difference between the HPLP mean scores of the students whose mothers were working and those whose mothers were not $(p=0.018)$. The students with a working mother had comparatively higher scores. Nevertheless, the study results suggested no statistically significany difference between the GSES mean scores of the participants whose mothers were working and the participants whose mothers were unemployed $(p=0.480)$. There was also a statistically significant difference between the income levels and HPLP mean scores $(p<0.001)$. Students with an adequate income had higher HPLP mean scores than those who stated that their income was partly adequate. On the other hand, the participants who had adequate or partly adequate income 
Binay and Yiğit

Adolescents' Health Promoting Lifestyle Behaviours and Self-Efficacy

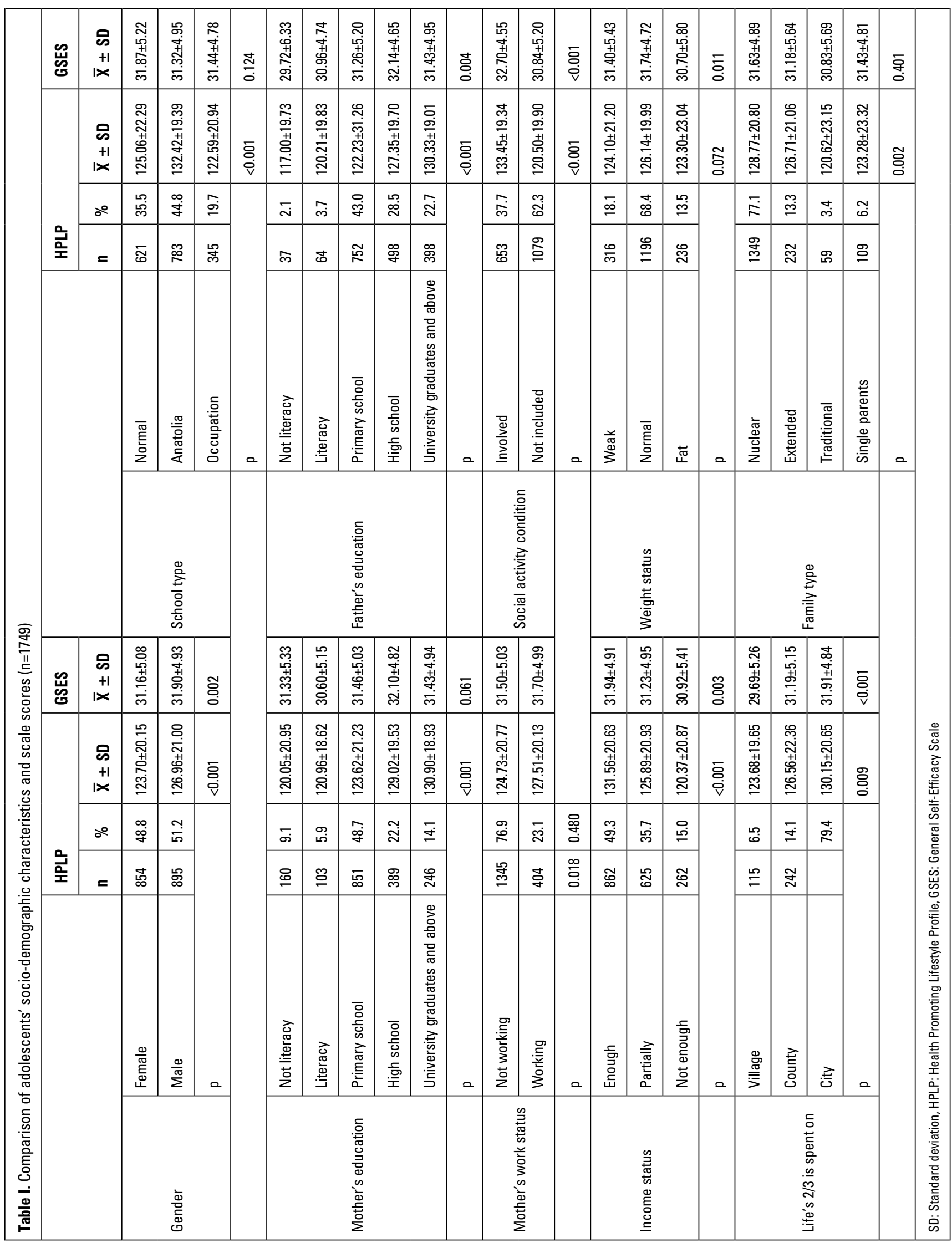


had higher scores than the participants who had inadequate income. There was a statistically significant difference between income levels and GSES mean scores ( $p=0.003$ ). The students with adequate income had higher GSES mean scores in comparison to the students with partly adequate or inadequate income. It was further reported that there was a statistically significant difference between the HPLP mean scores of students who took part in a social activity and the students who did not $(p<0.001)$. The students who participated in social activities had higher HPLP mean scores. There was also a statistically significant difference between GSES mean scores of both student groups $(p<0.001)$, which suggested that the students who participated in social activities had higher GSES mean scores. Self-perception of students towards their body weight wasn't significantly correlated with HPLP mean scores $(p=0.072)$ whereas there was a statistically significant difference between students' self-perception and GSES mean scores $(p=0.011)$. Those who thought that their weight was normal had higher GSES mean scores than those who found themselves overweight. The study results further emphasized that a statistically significant was reported between students' residence and HPLP mean scores $(p=0.009)$. The students who spent most of their lives in cities had higher HPLP mean scores than those with a rural background. There was also a statistically significant difference between their residence and GSES mean scores $(p<0.001)$. Students with a rural background had much lower GSES mean scores than those who lived in towns and cities. Finally, it was suggested that there was

Table II. Scale score and healthy lifestyle behaviors scale distribution of the scores obtained from the sub-group

\begin{tabular}{|c|c|c|c|c|}
\hline \multicolumn{3}{|l|}{ Scale score } & n & $X \pm S D$ \\
\hline \multicolumn{3}{|l|}{ HPLP } & 1749 & $127.88 \pm 21.16$ \\
\hline \multicolumn{3}{|l|}{ GSES } & 1749 & $31.53 \pm 5.02$ \\
\hline HPLP sub-groups & $\begin{array}{l}\text { Sub-group } \\
\text { of the item } \\
\text { number }\end{array}$ & $\begin{array}{l}\text { Minimum- } \\
\text { Maximum } \\
\text { score }\end{array}$ & n & $X \pm S D$ \\
\hline Self-actualization & 13 & $15-52$ & 1749 & $37.57 \pm 6.84$ \\
\hline Health responsibility & 10 & $10-40$ & 1749 & $21.19 \pm 5.49$ \\
\hline Exercise & 5 & $5-20$ & 1749 & $11.48 \pm 3.46$ \\
\hline Nutrition & 6 & $6-24$ & 1749 & $15.77 \pm 3.55$ \\
\hline Interpersonal support & 7 & 8-28 & 1749 & $20.42 \pm 3.90$ \\
\hline Stress management & 7 & $7-28$ & 1749 & $18.83 \pm 3.86$ \\
\hline
\end{tabular}

Table III. Correlation of scale score

\begin{tabular}{|l|l|l|}
\hline Scales & HPLP & GSES \\
\hline HPLP & - & $0.471(p<0.001)$ \\
\hline GSES & $0.471(p<0.001)$ & - \\
\hline HPLP: Health Promoting Lifestyle Profile, GSES: General Self-Efficacy Scale \\
\hline
\end{tabular}

a statistically meaningful difference between the family types and HPLP mean scores $(p=0.002)$. The participants with a nuclear family had higher HPLP mean scores than the participants with traditional or single parent families. However, the results didn't demonstrate a statistically significant difference between the family type and GSES mean scores $(p=0.401)$ (Table I).

\section{Discussion}

Walker et al. (14) defined health promotion model as "a multidimensional model of self-induced behaviors, perceptions that serve to protect and enhance well-being, and self-actualization and personal fulfillment", and developed HPLP to measure these behaviors and attitudes. The lowest possible score in HPLP is 48 and the highest is 192 (14). Higher scores of HPLP and subdimensions signify that the individual possesses positive health behaviors $(14,15,19-21)$.

Pender et al. (4) argued that the perception of self-efficacy is an important determinant of health promoting behaviors as well as physical, psychological, and environmental characteristcs of an individual, their motivation and general health conditions. Self-efficacy is defined as one's belief in his or her potential to perform a given task to achieve desired outcomes. GSE is a measurable characteristic that enables us to understand behaviors of an individual under different circumstances (22-24). Schwarzer and Jerusalem (15) developed scales to measure the psychological structure of individuals. GSES evaluates perceived self-efficacy in general terms, which particularly focuses on determining availability heuristics of an individual's efficacy to adapt and to cope with the challenges of everyday life (25). The lowest score is 10 and the highest score is 40 in GSES. Higher scores indicate higher levels of self-efficacy (16-18). Thousand seven hundred forty-nine adolescents in this study completed GSES with a mean score of $31.53 \pm 5.02$ which was above the average. Bandura's Social Cognitive Learning Theory implies that self-efficacy is directly influenced by social reactions (24). The results of the study demonstrated that the school types weren't significantly correlated with the scale scores. Moreover, mean scores of male students were found to be higher than those of female students, which complies with the results of studies on GSE that men had higher levels of self-efficacy than women $(18,26)$, which might refer to a correlation with cultural characteristics, child-rearing styles, and education system. McRae et al. (24) investigated the gender differences in controlling emotions and maintained that men were much more capable of controlling their negative emotions (27). The scores of HPLP and GSES were compared and consequently a positive significant correlation was reported. Health promoting behaviors mean score was found to increase with higher scores of selfefficacy. Unalan et al. (11) noted a positive significant correlation between self-care skills and health promoting behaviors. However, it is noteworthy to point out that selfcare and self-efficacy are conceptually different from each 
other. Self-care signifies a process that allows individuals to undertake the responsibility of their own and their families to develop a healthy lifestyle, to efficiently improve their skills and to encourage enterpreneurship (22). Self-efficacy, on the other hand, is a primary determinant that shapes and promotes human behaviors $(23,24)$. Maintaining selfcare definitely requires higher levels of self-efficacy (28). A literature review indicated that there were only a few studies that particularly compared health promoting behaviors and self-efficacy. Healthy behavior refers to all precautions to prevent or minimize illnesses and to protect and promote health. Positive health behaviors are conscious attitudes of individuals to protect their own and other people's health. The confidence that the individuals possess compatible skills in order to develop such behaviors is called the confidence of self-efficacy (23). Bandura suggests that it is a fundamental component of human behaviors (24). Health promoting behaviors serve to create a happy, successful, and quality life time. GSE is also instrumental in developing health promoting behaviors in all steps of life. It is often asserted that individuals with higher levels of self-efficacy are more successful in attaining their goals in life, which, in turn, brings more satisfaction into their private and professional lives.

\section{Conclusion}

Almost half of the participants in the study were male. A majority of all participants were 15 years old and spent most of their lives in urban settings. Almost half of the mothers were primary school graduates and almost all mothers were housewives. It was also reported that nearly half of the fathers were primary school graduates and the rest were high school or university graduates and almost all fathers were employed. It was noted that almost all families had social security and more than half of the families had adequate or partly adequate income. It was also stated that more than half of the adolescents in the study did not participate in a social activity. Additionally, more than half of the adolescents considered that their body weight was normal and their health was in better condition in comparison to their peers in the same socioeconomic class. HPLP total mean scores were found to be moderate and the highest HPLP subdimension scores were found in self-actualization, health responsibility, interpersonal support, stress management, diet, and exercise subdimensions, respectively. It was concluded that body weight perceptions of adolescents weren't correlated with HPLP mean scores. The male students in the study had higher HPLP mean scores than the female students. The adolescents from a traditional or single parent family, on the other hand, had lower HPLP mean scores than those coming from nuclear families. The adolescents whose parents had a high school degree or above were reported to have higher HPLP mean scores than the adolescents whose parents were illiterate, literate, and primary school graduates. The students with a working mother had higher HPLP mean scores. Moreover, the adolescents who participated in social activities were reported to have higher HPLP mean scores than those who did not. GSE mean scores were found to be moderate. The male students in this study had higher GSE scores than female students. Nevertheless, it was underlined that there was no significant correlation between family types, school types, and educational status of mothers and GSE mean scores. Besides, the adolescents who participated in social activities were found to have higher GSE mean scores. Those who perceived their body weight as normal had higher GSE mean scores than those who considered themselves overweight. It was finally maintained that the students who had higher HPLP mean scores also had higher GSE mean scores.

\section{Ethics}

Ethics Committee Approval: The study were approved by the Mersin University Scientific Researches Review Board and Mersin Provincial Directory of National Education, Informed Consent: Consent form was filled out by all participants.

Peer-review: Externally and Internally peer-reviewed.

\section{Authorship Contributions}

Surgical and Medical Practices: Şeyda Binay, Concept: Şeyda Binay, Rana Yiğit, Design: Şeyda Binay, Rana Yiğit, Data Collection or Processing: Şeyda Binay, Analysis or Interpretation: Şeyda Binay, Rana Yiğit, Literature Search: Şeyda Binay, Writing: Şeyda Binay.

Conflict of Interest: No conflict of interest was declared by the authors.

Financial Disclosure: The authors declared that this study has received no financial support.

\section{References}

1. Ball JW, Bindler RC. Child Health Nursing, Patnering with Children \& Families. 1st ed, USA, Pearson Prentice Hall, 2006.

2. Hockenberry MJ, Wilson D. Wong's Essentials of Pediatric Nursing. 9th ed, USA, Elsevier Mosby, 2013.

3. Mentes E, Mentes B, Karacabey K. Obesity and exercise in adoloscent period. The International Journal of Human Sciences 2011;8:963-7.

4. Pender NJ, Murdaugh C, Parsons MA. Health Promotion in Nursing Practice. 6th ed, Boston, MA: Pearson, 2011.

5. Bahar Z, Acil D. Health promotion model: Conceptual structure. DEUHYO ED 2014;7:59-67.

6. Coleman KJ, Geller KS, Rosenkranz RR, Dzewaltowski DA. Physical activity and healthy eating in the after-school environment. J Sch Health 2008;78:633-40.

7. Srof BJ, Velsor-Friedrich B. Health promotion in adolescents: a review of Pender's health promotion model. Nurs Sci $\mathrm{Q}$ 2006;19:366-73.

8. Von Ah D, Ebert S, Ngamvitroj A, Park N, Kang DH. Predictors of health behaviours in college students. J Adv Nurs 2004;48:463-74

9. Earvolino-Ramirez M. Commentary on "the influence of basic conditioning factors on healthy behaviors, self-efficacy, and self-care in adults". J Holist Nurs 2006;24:186-7. 
10. WHO. Self Care for Health: A Handbook for Community Health Workers \& Volunteers. Regional Office for South-East Asia, 2013.

11. Unalan D, Senol V, Ozturk A, Erkorkmaz U. A Research on The Relation between the Healthy Life Style Behaviors and Self-Care Levels of the Students in Health and Social Programs of Vocational Collages. Inönü Üniversitesi Tıp Fakültesi Dergisi 2007;14:101-9.

12. Geckil E, Yildiz S. The effect of nutrition and coping with stress education on adolescents' health promotion. Cumhuriyet Nurs J 2006;10:26-34.

13. Yalcinkaya M, Ozer Gok F, Karamanoglu AY. Evaluation of healthy lifestyle behaviors in ealth care workers. TAF Prev Med Bull 2007;6:409-20.

14. Walker SN, Sechrist KR, Pender NJ. The Health-Promoting Lifestyle Profile: development and psychometric characteristics. Nurs Res 1987;36:76-81.

15. Schwarzer R, Jerusalem M. Generalized self-efficacy scale. In: Weinman J, Wright S, Johnston M (eds). Measures in Health Psychology: A user's Portfolio. Causal and Control Beliefs Windsor, UK: NFER-Nelson1995. p. 35-7.

16. Esin MN. Adaptation of healthy lifestyle behaviors scale into Turkish. Bulletin of Nursing 1999;12:87-96.

17. Usta Yesilbalkan $O$, Karadakovan A. General self-efficacy of peritoneal dialysis patients. Journal of Nephrology Nursing 2005; 1:39-44.

18. Aypay A. The adaptation study of general self-efficacy (gse) scale to Turkish. Inonu University Journal Of The Faculty Of Education 2010;11:113-32.
19. Kaya F, Unuvar R, Bicak A. Health promoting behaviors of the lecturers and factors determining these behavior. TAF Prev Med Bull 1994;7:59-64.

20. Omisakin FD, Ncama BP. Self, self-care and self-management concepts: implications for self-management education. Educational Rese 2011;2:1733-7.

21. Bandura A. Self-efficacy. Enclopedia of Human Behavior 1994;4:71-81.

22. Bandura A. Social cognitive theory: an agentic perspective. Annu Rev Psychol 2001;52:1-26.

23. Netz $Y$, Raviv S. Age differences in motivational orientation toward physical activity: an application of social-cognitive theory. J Psychol 2004;138:35-48.

24. McRae K, Ochsner KN, Mauss IB, Gabrieli JJD, Gross JJ. Gender differences in emotion regulation: an fmrı study of cognitive reappraisal. Group Process Intergroup Relat 2008;11:143-62.

25. Tsay SL. Self-efficacy training for patients with end-stage renal disease. J Adv Nurs 2003;43:370-5.

26. Tulloch A. What do we mean by health? Br J Gen Pract 2005;55:320-3.

27. Musavian AS, Pasha A, Rahebi SM, Atrkar Roushan Z, Ghanbari A. Health promoting Behaviors Among Adolescents: A Cross-sectional Study. Nurs Midwifery Stud 2014;3:e14560.

28. Limnili G, Ozcakar N, Kartal M. Health promotion lifestyle profile scores are not associatedwith obesity in high school students. Turk J Med Sci 2016;46:1018-24 